\title{
Who is linking Macro- Imaging Technique to Real Micro-Biological World?
}

\section{Haitao Lu*}

Washington University School of Medicine, 660 S. Euclid Ave, 10306 BJC Institute of Health, St. Lou, MO 63110, USA

Multi-isotope imaging mass spectrometry, a novel technology, is striding forward in the biological world since first-time introduced in 2006 by Lechene et al. [1] in the Journal of Biology. It is possible to image and quantify molecules within individual mammalian or bacterial cells, by integrating secondary-ion mass spectrometer labeling with stable isotopes and building quantitative image-analysis software. The most striking feature of this technique is linking multi-isotope imaging technology to the real bio-molecule world. Just years accumulations in technology-innovation and practical application allow this young technology to more efficiently exploit unknown biological world from selective tissues or cells to universe biological molecules in mammalian or bacterial cells $[2,3]$, it is notable to beyond the peer biological technologies in tracking and characterizing bio-molecular signatures with stable isotope labeling. Real biological world is consisted of diverse and complicated biological molecular reactions with DNA, RNA, protein and metabolites involvements, the reorganization on signatures and behaviors of those involved molecules will lead to understanding of the relevant biological events, those processes could be easily comprehensible to be linking macro-phenotype to micromechanism. Multi-isotope imaging mass spectrometry is a promising technology by linking macro-mass spectrometry based multi-isotope imaging technology to micro-biological world, which allow multipleisotope imaging technology with mass spectrometry to globally and visibly characterize the most information-rich molecular phenotype across DNA, protein, lipid and small molecules, et al. Altogether, these predominant features have supported MIMS broad applications ranging from metabolism, cell biology, DNA/RNA biology, to biochemistry of biological macromolecules, now it could be predictable to present much broader application in biological and medical research, such as pathogenesis of diseases, biomarker discoveries for diseases diagnosis and treatment, identifications of therapeutic targets of the drug and tissue or cellar toxicology, plant biology, microbial metabolism and host pathogen interaction. This technology therefore could be an important complementation for the existed technology of biochemical/ chemical molecules profiling: metabolomics/metabonomics.

\section{References}

1. Claude Lechene, Francois Hillion, Greg McMahon, Douglas Benson, Alan M Kleinfeld, et al. (2006) High-resolution quantitative imaging of mammalian and bacterial cells using stable isotope mass spectrometry. Journal of Biology 5 : 20-29.

2. Steinhauser ML, Bailey AP, Senyo SE, Guillermier C, Perlstein TS, et al. (2012) Multi-isotope imaging mass spectrometry quantifies stem cell division and metabolism. Nature 481: 516-519.

3. Zhang DS, Piazza V, Perrin BJ, Rzadzinska AK, Poczatek JC, et al. (2012) Multi-isotope imaging mass spectrometry reveals slow protein turnover in haircell stereocilia. Nature 481: 520-524.
*Corresponding author: Haitao Lu, Washington University School of Medicine 660 S. Euclid Ave, 10306 BJC Institute of Health, St. Lou, MO 63110, USA, Tel: 1-314-580-9929; E-mail: hlu@dom.wustl.edu

Received February 01, 2012; Accepted February 09, 2012; Published February 11,2012

Citation: Lu H (2012) Who is linking Macro- Imaging Technique to Real MicroBiological World? J Bioequiv Availab 4: i-i. doi:10.4172/jbb.10000e11

Copyright: (c) 2012 Lu H. This is an open-access article distributed under the terms of the Creative Commons Attribution License, which permits unrestricted use, distribution, and reproduction in any medium, provided the original author and source are credited. 